that the manner of the petitioner's father's burial had been contrary to his wishes. Nevertheless, the chancellor held that the petitioner's belief that that was the case was a reasonable one, having an objective basis in fact. Faculties for exhumation were for the benefit of the living rather than the dead. Justification for what was proposed should, therefore, ultimately rest on what the petitioner believed on reasonable grounds. That did not necessarily mean that the court should grant the petition as sought: it would be possible for what the petitioner believed to represent his father's wishes to be fulfilled by his parents being re-interred together in the same cemetery. But the chancellor concluded that the court ought to facilitate 'the best possible solution' and that was represented by what the petitioner proposed. Following Re Blagdon Cemetery [2002] Fam 299, it was no longer necessarily objectionable to grant a faculty authorising re-interment in unconsecrated ground: it would depend on the facts of the particular case. The chancellor was prepared to assume that the re-interment in Belgium would be in land that would be suitably maintained and would be permanent. A faculty would be granted accordingly.

A further proposal contained in the petition involved the exhumation and cremation of the remains of the stillborn child in whose grave the petitioner's father had been buried and their interment in Kent, where the ashes of the child's father were interred. Subject to giving the petitioner the opportunity to request a hearing in open court on the question, a faculty would be refused for that aspect of the petition as there had been no mistake or misunderstanding surrounding the burial of the stillborn child and an exceptional circumstance had not been established. [Alexander McGregor]

doi:10.1017/So956618X11000603

\title{
Re All Saints, Ockbrook
}

Derby Consistory Court: Bullimore Ch, February 2011

Interment - cremated remains - closed churchyards

In granting a faculty for the interment of the cremated remains of the petitioners' parents (who had been resident in the parish) in a closed churchyard, the chancellor reviewed the law in relation to interments and closed churchyards. The petition was opposed by the incumbent and PCC because previous requests for interments had been refused on the basis that the churchyard was closed and therefore full. The chancellor held that the parish had been operating in ignorance of section 3(1) of the Church of England (Miscellaneous Provisions) Measure 1992. He further held that the petitioners had established 
a right to the interment of their parents' ashes in the area set aside in the churchyard for the interment of cremated remains pursuant to that section. [RA]

doi:10.1017/So956618X11000615

\author{
Moore v President of the Methodist Conference \\ Employment Appeal Tribunal: Underhill J, March 2011 \\ Methodist minister - employment status
}

The claimant, a Methodist minister, resigned from her appointment as minister to a group of congregations for a fixed period following what she felt was unfair pressure to do so. Her claim for unfair dismissal was dismissed on the basis that she was not an employee of the Church within the meaning of section 230 of the Employment Rights Act 1996 and that the tribunal was bound by the decision of the Court of Appeal in President of the Methodist Conference $v$ Parfitt [1984] ICR 176 in that respect. The claimant appealed. The Employment Appeal Tribunal (EAT) held that the reasoning in Parfitt could no longer be sustained in light of the decision of the House of Lords in Percy $v$ Board of National Mission of the Church of Scotland [2006] ICR 134. In Percy, the court had held that the spiritual role of a minister did not give rise to a presumption against an intention to create legal relations. In light of this, that spiritual role could not (as it had in Parfitt) support a specific finding that there was no intention to create legal relations. The EAT distinguished ordination from the claimant's specific appointment and held that the relationship between the claimant and the Church was contractual in nature, at least from the moment of her appointment, given the existence of terms in relation to remuneration, accommodation, holiday, sick pay, disciplinary procedures and expenses. The contract was one of service. The appeal was allowed and the matter was remitted to the Employment Tribunal for determination on its merits. [RA]

doi:10.1017/So956618X11000627

\title{
Kirk Session of Sandown Free Presbyterian Church's Application \\ High Court of Northern Ireland: Treacy J, March 2011 \\ Offensive advertisement - freedom of religion and expression - proportionality
}

The applicant sought judicial review of an adjudication by the Advertising Standards Agency (ASA) that an advertisement placed in the Belfast Newsletter headlined 'The Word of God against sodomy' would be likely to cause, and 